\title{
Research Instrument:CD-Based Multimedia Interactive Thematic on Integrative Learning in Elementary School
}

\author{
Reza Rachmadtulla \\ State University of Jakarta. Indonesia \\ E-mail: rezarachmadtullaheza@gmail.com \\ Phone : 08565358211
}

\section{Gird Instruments Expert Content}

\begin{tabular}{|l|l|l|c|c|}
\hline No. & \multicolumn{1}{|c|}{ Musty } & \multicolumn{1}{c|}{ Indicator } & item number & total \\
\hline 1. & \multirow{2}{*}{$\begin{array}{l}\text { Appropriateness } \\
\text { contents }\end{array}$} & $\begin{array}{l}\text { Suitability description of the } \\
\text { material with KD and Indicators }\end{array}$ & 1,2 & 2 \\
\cline { 3 - 5 } & & The accuracy of the material & 3.4 & 3 \\
\cline { 3 - 5 } & Learning support materials & $5,6,7,8$ & 3 \\
\hline \multirow{2}{*}{2.} & $\begin{array}{l}\text { Appropriateness } \\
\text { presentation } \\
\text { Materials }\end{array}$ & presentation techniques & 9,10 & 2 \\
\cline { 3 - 5 } & presentation Learning & 11,12, & 2 \\
\cline { 3 - 5 } & completeness of learning & $13,14,15,16,17$ & 2 \\
\cline { 3 - 5 } & $\begin{array}{l}\text { The suitability of the material } \\
\text { with } \\
\text { characteristics of students }\end{array}$ & 18 & 1 \\
\cline { 3 - 5 } & $\begin{array}{l}\text { the attractiveness of the } \\
\text { presentation } \\
\text { Matter }\end{array}$ & 20 & 19 \\
\cline { 3 - 5 } & $\begin{array}{l}\text { Suitability exercises } \\
\text { with indicators }\end{array}$ & 20 \\
\hline
\end{tabular}

\section{INSTRUMENT EXPERTS MATERIALS:}

STATEMENT

\begin{tabular}{|c|c|c|c|c|c|c|c|}
\hline \multirow[t]{2}{*}{ Indicator } & \multirow[t]{2}{*}{ Item Statement } & \multicolumn{5}{|c|}{ Score } & \multirow[t]{2}{*}{ Information } \\
\hline & & 1 & 2 & 3 & 4 & 5 & \\
\hline \multirow{2}{*}{$\begin{array}{l}\text { Suitability } \\
\text { description of } \\
\text { the material with } \\
\text { KD and } \\
\text { Indicators }\end{array}$} & $\begin{array}{l}\text { 1. completeness of the } \\
\text { materials }\end{array}$ & & & & & & \\
\hline & 2. the depth of material & & & & & & \\
\hline \multirow[t]{2}{*}{$\begin{array}{l}\text { Accuracy } \\
\text { Matter }\end{array}$} & $\begin{array}{l}\text { 3. The accuracy of the } \\
\text { facts and concepts }\end{array}$ & & & & & & \\
\hline & 4. Accuracy illustration & & & & & & \\
\hline \multirow[t]{2}{*}{$\begin{array}{l}\text { support materials } \\
\text { learning }\end{array}$} & $\begin{array}{l}\text { 5. Conformity with the } \\
\text { development of science }\end{array}$ & & & & & & \\
\hline & 6. Recency features, & & & & & & \\
\hline
\end{tabular}




\begin{tabular}{|c|c|c|c|c|c|c|c|c|}
\hline \multirow[t]{2}{*}{ Indicator } & \multirow{2}{*}{\multicolumn{2}{|c|}{ Item Statement }} & \multicolumn{5}{|c|}{ Score } & \multirow[t]{2}{*}{ Information } \\
\hline & & & 1 & 2 & 3 & 4 & 5 & \\
\hline & & example, and rujuka & & & & & & \\
\hline & & independent learning & & & & & & \\
\hline & & reasoning & & & & & & \\
\hline \multirow{2}{*}{$\begin{array}{l}\text { Technique } \\
\text { presentation }\end{array}$} & & keruntutan concept & & & & & & \\
\hline & & $\begin{array}{l}\text { consistency } \\
\text { systematics }\end{array}$ & & & & & & \\
\hline \multirow{2}{*}{$\begin{array}{l}\text { Presentation } \\
\text { learning }\end{array}$} & & Student-centered & & & & & & \\
\hline & & $\begin{array}{l}\text { variations in the } \\
\text { presentation }\end{array}$ & & & & & & \\
\hline \multirow[t]{5}{*}{$\begin{array}{l}\text { Completeness of } \\
\text { presentation } \\
\text { materials }\end{array}$} & & $\begin{array}{l}\text { Part predecessor (the } \\
\text { preface, instructions } \\
\text { for use, table of } \\
\text { contents) }\end{array}$ & & & & & & \\
\hline & & $\begin{array}{l}\text { The pictures and } \\
\text { illustrations } \\
\text { appropriate }\end{array}$ & & & & & & \\
\hline & & Exercises bervarias & & & & & & \\
\hline & & $\begin{array}{l}\text { Summary and map } \\
\text { concept }\end{array}$ & & & & & & \\
\hline & & $\begin{array}{l}\text { The suitability of the } \\
\text { material with the } \\
\text { scope of Civics }\end{array}$ & & & & & & \\
\hline $\begin{array}{l}\text { The suitability of } \\
\text { the material with } \\
\text { characteristics of } \\
\text { students }\end{array}$ & & $\begin{array}{l}\text { The material in } \\
\text { accordance with the } \\
\text { characteristics of class } \\
\text { V students }\end{array}$ & & & & & & \\
\hline $\begin{array}{l}\text { the attractiveness } \\
\text { of the } \\
\text { presentation } \\
\text { Matter }\end{array}$ & & $\begin{array}{l}\text { The material presented } \\
\text { easily understood by } \\
\text { students }\end{array}$ & & & & & & \\
\hline $\begin{array}{l}\text { Suitability } \\
\text { exercises } \\
\text { with indicators }\end{array}$ & & $\begin{array}{l}\text { Problem formative } \\
\text { according to the } \\
\text { indicator }\end{array}$ & & & & & & \\
\hline
\end{tabular}


GRID-GRID INSTRUMENTS FOR MULTIMEDIA EXPERTS

\begin{tabular}{|c|c|c|c|c|}
\hline No. & Musty & Indicator & item number & total \\
\hline \multirow[t]{7}{*}{1.} & \multirow[t]{7}{*}{ display } & Display Design / Layout Layout & 1,2 & 2 \\
\hline & & text Typography & $3,4,5$ & 3 \\
\hline & & Image on the media & $6,7,8$ & 3 \\
\hline & & Animation on media & 9,10 & 2 \\
\hline & & Audio & 11,12 & 2 \\
\hline & & illustration contents & 13,14 & 2 \\
\hline & & packaging & $15,16,17$ & 3 \\
\hline \multirow[t]{2}{*}{2} & \multirow[t]{2}{*}{ programming } & Use & $18,19,20,21,22$ & 4 \\
\hline & & Navigation and Interaktive link & 23,24 & 2 \\
\hline \multicolumn{4}{|c|}{ Total Item Questions } & 24 \\
\hline
\end{tabular}

\section{INSTRUMENT MULTIMEDIA:}

\begin{tabular}{|c|c|c|c|c|c|c|c|}
\hline \multirow[t]{2}{*}{ Indicator } & \multirow[t]{2}{*}{ Item Questions } & \multicolumn{5}{|c|}{ Score } & \multirow[t]{2}{*}{ Information } \\
\hline & & 1 & 2 & 3 & 4 & 5 & \\
\hline \multirow{3}{*}{$\begin{array}{l}\text { Display } \\
\text { Design / } \\
\text { Layout } \\
\text { Layout }\end{array}$} & $\begin{array}{l}\text { 1. The accuracy of the selection of } \\
\text { the material bacground }\end{array}$ & & & & & & \\
\hline & $\begin{array}{l}\text { 2. The accuracy of the proportion } \\
\text { of color to the layout }\end{array}$ & & & & & & \\
\hline & $\begin{array}{l}\text { 3. Not too many combinations of } \\
\text { colors on bacground }\end{array}$ & & & & & & \\
\hline \multirow{2}{*}{$\begin{array}{l}\text { Text/ } \\
\text { Typograph } \\
\text { y }\end{array}$} & \begin{tabular}{|l} 
4. The accuracy of that young \\
readable font selection
\end{tabular} & & & & & & \\
\hline & $\begin{array}{l}\text { 5. The accuracy of the font size for } \\
\text { readability }\end{array}$ & & & & & & \\
\hline \multirow[t]{4}{*}{$\begin{array}{l}\text { Image on } \\
\text { the media }\end{array}$} & $\begin{array}{l}\text { 6. The accuracy of the text color } \\
\text { for easy reading }\end{array}$ & & & & & & \\
\hline & 7. The composition of the picture & & & & & & \\
\hline & 8. $\quad$ The image size & & & & & & \\
\hline & 9. Quality image display & & & & & & \\
\hline \multirow{2}{*}{$\begin{array}{l}\text { animation } \\
\text { on } \\
\text { media }\end{array}$} & $\begin{array}{l}\text { 10. Compliance is animated by } \\
\text { material }\end{array}$ & & & & & & \\
\hline & 11. the attractiveness of animation & & & & & & \\
\hline \multirow[t]{2}{*}{ Audio } & $\begin{array}{l}\text { 12. Election statutes background } \\
\text { with the presentation of the } \\
\text { material }\end{array}$ & & & & & & \\
\hline & \begin{tabular}{|l|} 
13. Statutes sound and effects with \\
animation
\end{tabular} & & & & & & \\
\hline \multirow[t]{4}{*}{ packaging } & 14. Packaging front slide & & & & & & \\
\hline & $\begin{array}{l}\text { 15. Conformity with the display } \\
\text { contents }\end{array}$ & & & & & & \\
\hline & 16. Durability media & & & & & & \\
\hline & $\begin{array}{l}\text { 17. Appearance perspective center } \\
\text { (center point) good }\end{array}$ & & & & & & \\
\hline Use & 18. Conformity with the use of & & & & & & \\
\hline
\end{tabular}




\begin{tabular}{|c|c|c|c|c|c|c|c|}
\hline \multirow[t]{2}{*}{ Indicator } & \multirow{2}{*}{ Item Questions } & \multicolumn{5}{|c|}{ Score } & \multirow[t]{2}{*}{ Information } \\
\hline & & 1 & 2 & 3 & 4 & 5 & \\
\hline & $\begin{array}{l}\text { 19. Flexible (can be used } \\
\text { independently and guided) }\end{array}$ & & & & & & \\
\hline & $\begin{array}{l}\text { 20. Completeness of media usage } \\
\text { instructions }\end{array}$ & & & & & & \\
\hline & 21. The manual & & & & & & \\
\hline & $\begin{array}{l}\text { 22. Presenting the measure of } \\
\text { success of learning to use the } \\
\text { media }\end{array}$ & & & & & & \\
\hline \multirow{2}{*}{$\begin{array}{l}\text { Interactive } \\
\text { navigation } \\
\text { ling }\end{array}$} & $\begin{array}{l}\text { 23. Statutes use the navigation } \\
\text { symbol }\end{array}$ & & & & & & \\
\hline & $\begin{array}{l}\text { 24. Statutes performance intractive } \\
\text { link }\end{array}$ & & & & & & \\
\hline
\end{tabular}




\section{GRID GRID ASSESSMENT INSTRUMENT FOR STUDENTS}

\begin{tabular}{|c|c|c|c|c|}
\hline No. & Aspect & Indicator & Item numb & \\
\hline \multirow[t]{2}{*}{1} & \multirow{2}{*}{$\begin{array}{l}\text { Ease of Use } \\
\text { (Navigation) }\end{array}$} & Ease to interactive multimedia & 1,3 & 2 \\
\hline & & The clarity of the instructions for use & 2 & 1 \\
\hline \multirow[t]{4}{*}{2} & \multirow{4}{*}{$\begin{array}{l}\text { Aspect Display } \\
\text { (Display) }\end{array}$} & Clarity of writing, symbols and Pictures & 6.8 .9 & 3 \\
\hline & & $\begin{array}{l}\text { Interest in interactive multimedia } \\
\text { tamppilan }\end{array}$ & 7 & 1 \\
\hline & & Conformity with the material image & 10 & 1 \\
\hline & & views Baground & 4.5 & 2 \\
\hline \multirow[t]{2}{*}{3} & \multirow{2}{*}{$\begin{array}{l}\text { Quality } \\
\text { Content / } \\
\text { Content } \\
\text { (Countent } \\
\text { Quality) }\end{array}$} & $\begin{array}{l}\text { Ease in understanding } \\
\text { The concept of matter }\end{array}$ & $\begin{array}{c}11: 12: 13 \\
14: 15\end{array}$ & 5 \\
\hline & & $\begin{array}{l}\text { interest in using } \\
\text { teaching materials in the form of } \\
\text { interactive multimedia }\end{array}$ & $\begin{array}{c}16,17,18, \\
19,20\end{array}$ & 5 \\
\hline
\end{tabular}

\section{Statement}

\begin{tabular}{|c|c|c|c|c|c|c|}
\hline \multirow[t]{2}{*}{ No. } & \multirow[t]{2}{*}{ Statement } & \multicolumn{5}{|c|}{ Value } \\
\hline & & 1 & 2 & 3 & 4 & 5 \\
\hline 1 & Easy to use interactive multimedia & & & & & \\
\hline 2 & Interactive multimedia usage instructions are easy to understand & & & & & \\
\hline 3 & The program can run well or did not hang (stop) & & & & & \\
\hline 4 & views Bagroundlooks interesting & & & & & \\
\hline 5 & color pada Baground looks interesting & & & & & \\
\hline 6 & Bentuk letters used visible and attractive & & & & & \\
\hline 7 & The pictures in the visible and attractive multimedia & & & & & \\
\hline 8 & Images are presented in accordance with the material & & & & & \\
\hline 9 & $\begin{array}{l}\text { Display Menu, author, back, next, the sound does not have to } \\
\text { hang }\end{array}$ & & & & & \\
\hline 10 & $\begin{array}{l}\text { Illustrations are presented in a clear, interesting, and in } \\
\text { accordance with the material }\end{array}$ & & & & & \\
\hline 11 & Maanchovies served lightly with their illustrations & & & & & \\
\hline 12 & Materi easily linked to the experience I had & & & & & \\
\hline 13 & Maanchovies served easily understood & & & & & \\
\hline
\end{tabular}




\begin{tabular}{|c|c|c|c|c|c|c|}
\hline \multirow[t]{2}{*}{ No. } & \multirow[t]{2}{*}{ Statement } & \multicolumn{5}{|c|}{ Value } \\
\hline & & 1 & 2 & 3 & 4 & 5 \\
\hline 14 & $\begin{array}{l}\text { meinteractive multimedia've been through this, I can write the } \\
\text { purpose of learning }\end{array}$ & & & & & \\
\hline 15 & $\begin{array}{l}\text { meThe media are going through, I can check the results of my } \\
\text { own work }\end{array}$ & & & & & \\
\hline 16 & sayA can provide an assessment of the results of my own work & & & & & \\
\hline 17 & $\begin{array}{l}\text { meinteractive multimedia've been through this, I can write what } \\
\text { is less understood than this material }\end{array}$ & & & & & \\
\hline 18 & $\begin{array}{l}\text { sayA can understand the material on subjects PPKn using } \\
\text { interactive multimedia without the help of teachers or others }\end{array}$ & & & & & \\
\hline 19 & $\begin{array}{l}\text { saya can resolveexercise in media this with my own ability and } \\
\text { effort }\end{array}$ & & & & & \\
\hline 20 & sayA more confident in my skills & & & & & \\
\hline 21 & $\begin{array}{l}\text { meThe media are going through, I can check the results of my } \\
\text { own work }\end{array}$ & & & & & \\
\hline 22 & sayA can provide an assessment of the results of my own work & & & & & \\
\hline
\end{tabular}

